\title{
PENERAPAN PASAL 77 KUHP TENTANG GUGURNYA HAK MELAKUKAN \\ PENUNTUTAN DALAM PROSES PERSIDANGAN \\ (Kajian Yuridis Atas Produk Hukum Yang Dikeluarkan Hakim Studi Kasus di \\ Pengadilan Negeri Purbalingga \\ Neden Rika Puspitasari \\ (Hakim Pengadilan Negeri J ogjakarta)
}

\begin{abstract}
The fall of the right to prosecute in respect of the accused had died regulated in article 77 KUHP. Product of law that issued by judge can be determination of law or legal judgement.

The application of law in practical based on some product law that issued by a judge, either the determination or decision always faced to three aspects of the legal objectivities to be achieved such as, legal certainly, expediency or justice.
\end{abstract}

Keyword: Determination, decision, purpose of law

\begin{abstract}
Abstrak
Jatuhnya hak untuk mengadili berkenaan dengan terdakwa telah meninggal diatur dalam pasal 77 KUHP. Produk hukum yang dikeluarkan oleh hakim dapat menentukan hukum atau pertimbangan hukum.

Penerapan hukum secara praktis berdasarkan beberapa undang-undang produk yang dikeluarkan oleh hakim, entah penentuan atau keputusan selalu dihadapkan pada tiga aspek objektivitas hukum yang harus dicapai seperti, tentu saja legal, kemanfaatan atau keadilan.
\end{abstract}

Kata Kunci: Penentuan, keputusan, tujuan hukum

\section{PENDAHULUAN}

Kewenangan mengadili perkara-perkara pidana yang melibatkan masyarakat umum atau sipil oleh negara diberikan kepada peradilan umum sebagaimana tertuang dalam Pasal 1 butir ke-1 Undang-Undang Nomor 49 Tahun 2009 tentang Perubahan atas Undang-undang Nomor 8 Tahun 2004 dan Undang-undang Nomor 2 Tahun 1986 tentang Peradilan Umum yang mengatur tentang peradilan di bawah Mahkamah Agung yang menyebutkan: Pengadilan adalah pengadilan negeri dan pengadilan tinggi di lingkungan peradilan umum. Berdasarkan kewenangan tersebut maka peradilan umum dalam hal ini pengadilan negerilah yang sering kali terdapat hal-hal yang di luar hukum acara yang perlu diterapkan oleh hakim dalam menangani perkara pidana yang diperiksa dan diadilinya.

Sistem peradilan pidana di Indonesia saat ini yang bertumpu pada Undang-Undang Nomor 8 Tahun 1981 tentang Kitab Undang-Undang Hukum Acara Pidana dirasakan telah ketinggalan jaman. Diperlukan suatu sistem baru yang mendukung perlakuan yang lebih berimbang terhadap tersangka, terdakwa ataupun terpidana dan juga perlakuan terhadap korban kejahatan maupun terhadap saksi-saksi dalam perkara pidana sehingga sistem peradilan pidana di Indonesia lebih bersifat komprehensif 
dan mengakomodir kepentingan semua pihak yang bersinggungan dengan hukum pidana dalam proses penegakan hukum pidana.

Dalam penegakan hukum pidana, kedudukan hakim sebagai penentu hukuman seringkali juga berada dalam posisi yang dipertanyakan oleh masyarakat luas terhadap hukuman yang dijatuhkannya. Padahal di sisi lain penjatuhan pidana hanyalah merupakan salah satu bagian akhir dari rangkaian proses hukum acara pidana, yang berawal dari penyelidikan dan penyidikan. Hakim dalam menjalankan tugasnya semata-mata menerima, memeriksa dan mengadili suatu perkara pidana yang kesemuanya itu didasarkan pada adanya hukum acara pidana yang memagarinya. Ketaatan dalam menjalankan hukum acara pidana merupakan salah satu syarat agar proses beracara pidana sampai pada penjatuhan putusannya dapat dipertanggungjawabkan selain dari nilai kepantasan dan keadilan dalam menjatuhkan putusan.

Berkaitan dengan ketentuan dalam Pasal 77 KUHP, yang menyebutkan Kewenangan menuntut pidana hapus, jika tertuduh meninggal dunia. ${ }^{1}$ Dalam hal ini pejabat yang menentukan perkara gugur selama proses persidangan adalah Hakim, dan menjadi permasalahan selanjutnya adalah sebagai pejabat yang ditunjuk oleh undang-undang untuk menentukan status perkara pidana dinyatakan gugur apakah melalui produk hukum berupa putusan ataukah berupa penetapan. Bagaimanakah hal-hal tersebut diterapkan dalam praktik?

1 Moeljatno, 2007, Kitab Undang-undang Hukum Pidana, Jakarta, Bumi Aksara, hlm 18.

\section{PEMBAHASAN}

Teori besar yang ingin disampaikan yaitu teori keadilan, yang oleh Aristoteles diartikan:

Keadilan adalah tindakan yang terletak diantara memberikan sesuatu terlalu banyak dan sedikit, atau juga dapat diartikan memberikan sesuatu kepada setiap orang sesuai dengan apa yang menjadi haknya. $^{2}$

Pengertian tentang keadilan yang lain yaitu menurut Notonegoro, yang menerangkan sesuatu perbuatan dikatakan adil jika sesuai dengan ketentuan hukum yang berlaku. Dalam konteks hukum pidana maka suatu perbuatan dikatakan adil jika seseorang tidak melanggar kaidah-kaidah dalam hukum pidana materiil yaitu sesuatu yang bersifat larangan untuk berbuat atau tidak berbuat. Penerapan hukum pidana materiil tersebut maka dipergunakanlah hukum pidana formil atau hukum acara pidana.

Selanjutnya penelitian terhadap efektivitas hukum yang merupakan penelitian yang membahas bagaimana hukum beroperasi dalam masyarakat, penelitian ini sangat relevan di negara-negara berkembang seperti Indonesia, penelitian ini mensyaratkan penelitinya di samping mengetahui ilmu hukum juga mengetahui ilmu sosial, dan memiliki pengetahuan dalam penelitian ilmu sosial (social science research). ${ }^{3}$

Faktor-faktor yang dapat mempengaruhi hukum itu berfungsi dalam masyarakat, yaitu:

a. Kaidah hukum/peraturan itu sendiri.

2 www.artikelsiana.com/2015/01/pengertian keadilan-macam-macam-keadilan. html diakses J umat, 04/03/2016 jam 16.11 Wib.

3 Zainuddin Ali, Metode Penelitian Hukum, Sinar Grafika, J akarta, 2014, hlm 31. 
b. Petugas/penegak hukum.

c. Sarana atau fasilitas yang digunakan oleh penegak hukum.

\section{d. Kesadaran masyarakat. ${ }^{4}$}

Lawrence M. Friedman mengemukakan bahwa, efektif dan berhasil tidaknya penegakan hukum tergantung tiga unsur sistem hukum, yakni struktur hukum (struktur of law), substansi hukum (substance of the law) dan budaya hukum (legal culture). Struktur hukum menyangkut aparat penegak hukum, substansi hukum meliputi perangkat perundang-undangan dan budaya hukum merupakan hukum yang hidup (living law) yang dianut dalam suatu masyarakat. ${ }^{5}$

Struktur hukum dalam hal ini yaitu para pelaku di dalamnya misalnya Pengadilan, Kejaksaan ataupun Kepolisian, substansi hukum yang dimaksud oleh Friedman yaitu berkaitan dengan peraturan-peraturan yang ada, normanorma yang ada dan budaya hukum berkaitan dengan perilaku budaya hukum yang ada dalam masyarakat maupun perangkat hukum.

Pengertian di atas mendasari bahwa produk hukum sebagaimana pendapat Friedman maupun Montesquie merupakan bagian substansi hukum, dalam suatu masyarakat modern yang demokratis senantiasa diperlukan keterlibatan dari masyarakat dalam proses pembuatan dan penyusunannya, sehingga berkenaan dengan produk hukum tertentu untuk dibahas maka diundangkannya Kitab Undangundang Hukum Pidana merupakan produk hukum materiil yang sampai saat ini masih

Ibid

5 Zenhadianto.blogspot.co.id/2014/01/teori-sistem hukum-lawrance-m-friedman.html, diakses jum'at 04/03/2016 jam 16.20 WIB. dipergunakan untuk menjalankan fungsi pengaturan dalam masyarakat di Indonesia khususnya pengaturan di bidang hukum pidana.

Sebagai bagian substansi hukum maka hukum pidana menurut Satochid Kartanegara terdiri dari: ${ }^{6}$

1. Hukum Pidana Materiil.

Hukum pidana materiil menunjukkan strafbaare feiten beserta hukum-hukumnya. ${ }^{7}$ Strafbaar feiten adalah perbuatan-perbuatan yang oleh undang-undang dengan tegas dinyatakan dapat dihukum. Terhadap suatu perbuatan dapat dijatuhkan hukuman bila perbuatan itu didahului oleh ancaman hukuman oleh undang-undang. Menurut Moch. Faisal Salam, hukum pidana adalah semua peraturan-peraturan yang meliputi seluruh peraturan yang jika dilanggar diancam dengan hukuman badan atau denda. ${ }^{8}$ Yang dimaksud seluruh peraturan diartikan bahwa bukan saja ketentuan dalam KUHP akan tetapi ketentuan yang tersebar dalam berbagai undang-undang misalnya Undang-Undang Senjata Api, UndangUndang Lalu Lintas, Undang-Undang Tindak Pidana Ekonomi dan lain-lain. Berdasar pasal 103 KUHP membuka peluang berlaku ketentuan pidana yang diatur di luar KUHP. ${ }^{9}$

Hukum pidana materiil adalah hukum yang menentukan perbuatan apa yang dapat dipidana, siapa-siapa yang dapat dipidana dan pidana-pidana apa yang dapat dijatuhkan. Satochid Kartanegara berkaitan

Satochid Kartanegara, tanpa tahun, Hukum Pidana, Kumpulan Kuliah, Bagian Dua, Balai Lektur Mahasiswa, hlm 501.

Ibid.

8 Moch. Faisal Salam, 2001, Hukum Acara Pidana dalam Teori dan Praktek, Bandung, Mandar Maju, hlm 2.

Ibid. 
dengan hukum pidana materiil ini selanjutnya menambahkan: ${ }^{10}$

Suatu perbuatan tidak dapat dihukum, kecuali bila kekuatan peraturan undangundang pidana mendahului-nya (Pasal 1 KUHP). Lengkapnya, pada Pasal 1 berbunyi: Tidak ada perbuatan yang boleh dihukum, selain atas kekuatan aturan pidana didalam undang-undang yang diadakan pada waktu sebelumnya perbuatan itu terjadi. Pasal 1 KUHP ini, bersumber dari ajaran Montesquieu, yaitu azas perihal pemishan kekuasaan. Menurut ajaran tersebut, tugas hakim terbatas pada menjalankan undangundang. Pasal 1 KUHP adalah merupakan jaminan bagi suatu rechtsveligheid (keamanan hukum), sebagai jaminan atau untuk menghindari dari perbuatan sewenang-wenangan dari hakim, maksudnya suatu perbuatan bila tidak dengan tegas dinyatakan didalam undang-undang.

Hukum pidana yang berlaku di Indonesia sekarang ini ialah hukum pidana yang telah dikodifikasi, yaitu sebagian terbesar dan aturan-aturannya telah disusun dalam satu kitab undang-undang (wetboek), yang dinamakan Kitab Undang-undang Hukum Pidana, menurut suatu sistem yang tertentu. ${ }^{11}$ Selain daripada hukum pidana kita telah dikodifikasi maka bagian hukum ini juga telah diunifikasi, yaitu berlaku bagi semua golongan rakyat, sehingga tidak ada dualisme lagi seperti dalam hukum perdata, di mana bagi golongan rakyat Bumiputera

Satochid Kartanegara, Op. cit, hlm 501.

Moeljatno, 2015, Asas-asas Hukum Pidana, Edisi Revisi, J akarta : Rineka Cipta, hlm 17. berlaku hukum yang lain daripada yang berlaku bagi golongan Eropa. ${ }^{12}$

Berdasarkan sejarahnya maka Mardjono Reksodiputro dalam bukunya Pembaharuan Hukum Pidana telah menuliskan: ${ }^{13}$

Kitab Undang-undang hukum Pidana (KUHP) yang sekarang berlaku (S.1915 No. 732) telah melakukan fungsinya untuk lebih dari 75 tahun, akan tetapi sudah tidak cukup lagi memenuhi keperluan masyarakat Indonesia. Karena itulah dilakukan upaya pembaharuan KUHP oleh suatu Tim RUU Hukum Pidana yang mulai bekerja pada tahun 1982 di Departemen Kehakiman (mula-mula di bawah Badan Pembinaan Hukum Nasional dan kemudian pada Direktorat Jenderal Hukum dan Perundang-Undangan). KUHP 1915 (KUHP Hindia Belanda), yang mulai berlaku pada tahun 1918, telah mengalami banyak penambahan dan perubahan, baik pada masa Hindia Belanda maupun masa Republik Indonesia. Baik oleh pemerintah Hindia Belanda yang pada masa pendudukan militer Jepang berpindah ke Australia, maupun oleh pemerintahan NICA (Netherlands Indies Civil Administration) di daerah pendudukannya di Indonesia, ataupun oleh pemerintah Republik Indonesia yang terbentuk sejak bulan Agustus 1945. Keadaan ini menimbulkan adanya dualisme dalam hukum pidana yang berlaku di Indonesia sejak tahun 1945. Hal ini baru berubah ketika dengan UU No. 73 Tahun

2 Ibid, hal 18.

13 Mardjono Reksodiputro, 1997, Pembaharuan Hukum Pidana, Pusat Pelayanan Keadilan dan Bantuan Hukum, Universitas Indonesia, hlm 21. 
1958 telah dinyatakan berlaku UU No.1 Tahun $1946 \mathrm{Rl}$ tentang Peraturan Hukum Pidana Untuk Seluruh Wilayah Republik Indonesia Dan Mengubah Kitab Undangundang Hukum Pidana. Kitab UndangUndang Hukum Pidana yang dipergunakan sebagai dasar untuk rekodifikasi adalah Wetboek van Strafrecht voor NederlandschIndie dengan segala perubahannya sampai 8 Maret 1942 (penyerahan Indonesia oleh pemerintah Hindia Belanda kepada pemerintah militer Jepang), dan yang kemudian telah dinyatakan berlaku untuk seluruh wilayah Republik Indonesia melalui UU No. 1/1946 dan UU No. 73/1958 serta seluruh perubahan yang dilakukan oleh pemerintah Republik Indonesia setelah itu.

Dapat ditambahkan, dalam sejarahnya karena di Indonesia warganya terdiri dari berbagai golongan maka bagi tiap golongan penduduk Indonesia dibuat kitab Undangundang Hukum Pidana sendiri sebagai berikut $:^{14}$

a. Wetboek van Strafrecht voor Nederlansch Indie untuk golongan, penduduk Eropa, ditetapkan dengan "Koninklijk Besluit" 10 Februari 1866, berisi hanya meliputi kejahatan-kejahatan saja.

b. Wetboek van Strafrecht voor Nederlansch Indie untuk golongan penduduk Indonesia dan Timur Asing, ditetapkan dengan "Ordonantie" 6 Mei 1872, hanya berisi kejahatan-kejahatan saja. c. Algemeene Politie Strafreglement untuk golongan penduduk Eropa, ditetapkan dengan "Ordonantie" 15 Juni 1872, berisi hanya pelanggaran-pelanggaran saja.

d. Algemeene Politie Strafreglement untuk golongan penduduk Indonesia dan Timur Asing, ditetapkan dengan "ordonantie" 15 Juni 1872, berisi hanya pelanggaran-pelanggaran saja.

2. Hukum Pidana Formil.

Ketentuan-ketentuan perundang-undangan yang mengatur prosedur agar pelaku pelanggaran dan kejahatan dapat dihadapkan kemuka sidang pengadilan dinamakan hukum pidana formil. ${ }^{15}$ Dengan kata lain, bahwa hukum pidana formil adalah kumpulan peraturan-peraturan hukum yang memuat ketentuan-ketentuan yang mengatur hal-hal sebagai berikut :

a. Tindakan-tindakan apa yang harus diambil apabila ada dugaan, bahwa telah terjadi suatu tindak pidana dilakukan oleh seseorang.

b. Apabila benar telah terjadi suatu tindak pidana yang dilakukan oleh seseorang, maka perlu diketahui, siapa pelakunya dan cara bagaimana melakukan penyelidikan terhadap pelaku.

c. Apabila telah diketahui pelakunya maka penyelidik perlu menangkap, menahan kemudian dilanjutkan dengan pemeriksaan permulaan atau dilakukan penyidikan. 
d. Untuk membuktikan apakah tersangka benar-benar melakukan suatu tindak pidana, maka perlu mengumpulkan barang-barang bukti, menggeledah badan dan tempat-tempat serta menyita barang-barang bukti yang diduga ada hubungannya dengan perbuatan tersebut.

e. Setelah selesai dilakukan pemeriksaan permulaan atau penyidikan oleh polisi, maka berkas perkara diserahkan pada kejaksaan negeri, selanjutnya pemeriksaan dalam sidang pengadilan terhadap terdakwa oleh hakim sampai dapat dijatuhkan pidana.

Sejarah singkat hukum pidana formil di Indonesia berawal pada waktu negeri Belanda dijajah oleh Perancis, sehingga berlaku hukum pidana Perancis yang disebut "Code Penal", dan setelah Belanda berhasil mengusir Perancis maka Belanda membuat sendiri Kitab Undangundang Hukum Pidananya yang disebut dengan "Nederlansch Wetboek van Strafrecht". Oleh karena adanya asas konkordansi maka Indonesia yang saat itu merupakan jajahan Belanda sehingga yang berlaku di Indonesia adalah juga hukum pidana yang berlaku di negeri Belanda termasuk pula hukum pidana formilnya yang terdiri :
a. Reglement op de Rechterlijke Organisatie (Stbl 1848 No. 57) yang memuat ketetapan-ketetapan mengenai organisasi dan peraturan kehakiman.

b. Reglement op de burgerlijke Rechtsvordering (Stbl 1849 No. 63) yang memuat hukum acara perdata bagi golongan penduduk Eropa dan yang disamakan dengan mereka.

c. Reglement op de Strafvordering (Stbl 1849 No. 63) yang memuat hukum acara pidana bagi golongan penduduk Eropa dan yang disamakan dengan mereka.

d. Landgerechtsreglement (Stbl 1914 No. 317) yang memuat acara dimuka pengadilan Landgerecht yang memutus perkara-perkara kecil untuk segala bangsa, dan yang terpenting.

e. Inlands Reglement, yang biasa disingkat I.R (Stbl 1848 No. 16) memuat hukum acara perdata dan hukum acara pidana di muka pengadilan "Landraad" bagi golongan penduduk Indonesia dan Timur Asing, hanya berlaku di Jawa dan Madura, sedangkan untuk luar Jawa dan Madura yang berlaku Rechtsreglement voor de Buitengewesten (Stbl 1927 No. 227).

Selanjutnya hukum acara perdata dan hukum acara pidana untuk golongan penduduk Indonesia dan Timur Asing (Stbl 1927 No. 227) dirubah dengan Stbl 1941 No. 44 yang namanya berubah menjadi "Herzien Inlandsch Reglement" atau disingkat H.I.R. Kemudian berpindah ke masa penjajahan Jepang, maka untuk semua golongan penduduk, kecuali bangsa Jepang, di Indonesia hanya terdapat 
dua pengadilan yaitu "Tiho Hooin" dan "Keizai Hooin" yang merupakan kelanjutan pengadilan pada waktu penjajahan Belanda "Landraad" dan "Landerecht" dan yang dipergunakan sebagai hukum acara adalah "Herzien Inlandsch Reglement dan Landgerechtsreglement".

Setelah Indonesia merdeka sesuai dengan ketentuan yang ada dalam Pasal II Aturan Peralihan Undang-Undang Dasar 1945 yang berbunyi:

Segala badan negara dan peraturan yang ada masih langsung berlaku, selama belum diadakan yang baru menurut Undang-undang Dasar ini.

Berdasarkan Pasal II Aturan Peralihan tersebut, maka Herzien Inlandscht Reglement dan Landgerechtsreglement diberlakukan setelah Indonesia merdeka. Pada tahun 1951 dikeluarkanlah Undang-undang Darurat Nomor 1 Tahun 1951 tentang Tindakan-tindakan Sementara Untuk Menyelenggarakan Kesatuan Dalam Susunan, Kekuasaan dan Acara Pengadilan-pengadilan Sipil di Indonesia, sehingga dengan adanya undang-undang darurat tersebut merupakan dasar dari peradilan yang berlaku di seluruh Indonesia dan untuk semua golongan penduduk yaitu:
a. Pengadilan
Negeri untuk pemeriksaan tingkat pertama;
b. Pengadilan Tinggi untuk pemeriksaan tingkat banding;
c. Mahkamah Agung untuk pemeriksaan tingkat kasasi;
Pasal 6 Undang-Undang Darurat Nomor 1 Tahun 1951 menetapkan bahwa untuk seluruh Indonesia berlaku sebagai pedoman untuk acara perkara pidana di Pengadilan
Negeri berlaku Herzien Inlandsch Reglement (HIR) yang merupakan perbaikan dari Inlandsch Reglement yang disesuaikan dengan Inlandsch Reglement yang berlaku untuk orang Eropa, dimana yang diambil adalah bagian-bagian yang baik dan cocok untuk orang Indonesia. Oleh karena itu setelah Indonesia merdeka HIR tetap diberlakukan sebagai hukum acara pidana sebagai pedoman bagi acara pidana pada Pengadilan Negeri.

Dalam hukum pidana yang harus dipedomani adalah hukum pidana materiil yaitu berupa seperangkat peraturan perundangundangan di bidang hukum pidana yang harus ditegakkan dan diterapkan misalnya ketentuanketentuan dalam Kitab Undang-Undang Hukum Pidana (KUHP), dan untuk menjamin penegakkan hukum terhadap aturan tersebut maka dipergunakan hukum pidana formil dalam hal ini Undang-undang No. 8 Tahun 1981 atau lebih dikenal dengan Kitab Undang-Undang Hukum Acara Pidana (KUHAP). Namun demikian selain dari KUHP dan KUHAP tersebut di Indonesia juga masih diberlakukan pula ketentuan hukum pidana materiil maupun formil di luar dari kedua ketentuan tersebut yang bersifat kekhususan sebagai contoh salah satunya yaitu Undang-Undang Nomor 35 Tahun 2009 tentang Narkotika yang mengatur tentang hukum pidana materiil maupun formil di bidang tindak pidana narkotika.

Dalam praktik, produk hukum yang dapat dikeluarkan oleh hakim dalam perkara pidana ada 2 (dua) yaitu penetapan dan putusan. Undang-undang tidak mendefinisikan secara jelas mengenai definisi Penetapan Hakim dalam perkara pidana. Dari berbagai 
literatur yang diperoleh terdapat beberapa pengertian hukum tentang Penetapan Hakim namun pengertian tersebut lebih menjelaskan tentang Penetapan yang dikeluarkan oleh hakim yang berkaitan dengan produk hukum perkara perdata, akan tetapi sebagai sebuah produk hukum yang dikeluarkan oleh hakim maka pada dasarnya pengertian Penetapan Hakim dalam perkara pidana maupun Penetapan Hakim dalam perkara perdata pada dasarnya tidaklah jauh berbeda dimana dalam pengertian Penetapan Hakim perkara perdata disebutkan Penetapan adalah keputusan pengadilan atas perkara permohonan (volunter), misalnya penetapan dalam perkara dispensasi nikah, izin nikah, wali adhal, poligami, perwalian, itsbat nikah, dan sebagainya. ${ }^{16}$ Bertitiktolak pada pengertian tersebut maka dapat diartikan Penetapan Hakim dalam perkara pidana adalah keputusan pengadilan dalam hal ini hakim terhadap hal-hal tertentu selain daripada putusan baik putusan sela maupun putusan akhir, seperti penetapan hari sidang, penetapan perpanjangan penahanan dan sebagainya dengan kata lain penetapan merupakan keputusan atau sikap hakim yang dituangkan dalam sebuah produk surat berisi hal-hal tertentu yang menunjukkan sikap dari Majelis Hakim/Hakim terhadap suatu proses perkara pidana.

Secara umum ketentuan tentang gugurnya hak melakukan tuntutan pidana terhadap terdakwa/tersangka/tertuduh dalam KUHP diatur dalam Bab VIII Buku I mengenai

16 https://smjsyariah89.wordpress.com/2011/06/20/ penetapan-dan-putusan/diunduh 09/11/2015 hapusnya kewenangan menuntut pidana dan menjalankan pidana yang meliputi :

a. Telah ada putusan hakim yang tetap (de kracht van een recterlijk gewijsde) mengenai tindakan (feit) yang sama (ps. 76);

b. Terdakwa meninggal (ps. 77);

c. Perkara tersebut daluarsa (ps. 78);

d. Terjadi penyelesaian di luar persidangan (ps. 82); ${ }^{17}$

Ahli hukum Gustav Radburch pernah menyampaikan teorinya bahwa suatu produk hukum yang dikeluarkan oleh hakim senantiasa harus memedomani 3 (tiga) hal yaitu kepastian hukum, kemanfaatan dan keadilan. Sehingga sejauhmana produk hukum yang dikeluarkan oleh hakim berkaitan dengan ketentuan Pasal 77 KUHP dapat menjawab teori hukum yang dikemukakan oleh Gustav Radburch tersebut tentunya bagi seorang hakim menjadi tantangan tersendiri.

Penetapan merupakan keputusan atau sikap hakim yang dituangkan dalam sebuah produk surat berisi hal-hal tertentu yang menunjukkan sikap dari Majelis Hakim/Hakim terhadap suatu proses perkara pidana. Penetapan yang dikeluarkan oleh Majelis Hakim sehubungan dengan meninggalnya terdakwa pada saat proses persidangan masih berlangsung sebagaimana ketentuan dalam Pasal 77 KUHP, secara teoretis masih dapat diperdebatkan apakah lebih baik menggunakan produk hukum berupa penetapan ataukah menggunakan produk hukum berupa putusan.

E.Y.Kanter, dan Sianturi, S.R , 2002, Asas-asas Hukum Pidana di Indonesia dan Penerapannya, J akarta, Storia Grafika, hlm 427. 
Sedangkan pengertian putusan adalah suatu pernyataan oleh hakim sebagai pejabat negara yang diberi wewenang untuk itu, diucapkan di persidangan dan bertujuan untuk atau sengketa antara para pihak. ${ }^{18}$ Dalam perkara perdata penetapan didefinisikan yaitu keputusan pengadilan atas perkara permohonan (volunter), misalnya:

Penetapan dalam perkara dispensasi nikah, izin nikah, wali adhal, poligami, perwalian, itsbat nikah, dan sebagainya. Penetapan berarti bukan peradilan yang sesungguhnya karena pada penetapan hanya ada permohon tidak ada lawan hukum. Didalam penetapan, Hakim tidak menggunakan kata "mengadili", namun cukup dengan menggunakan kata "menetapkan". ${ }^{19}$

Dalam perkara pidana terdapat dua produk hukum yang dapat dikeluarkan oleh hakim yaitu penetapan dan putusan, dari uraian di atas maka dapat dipahami bahwa adanya kejadian terdakwa meninggal dunia di persidangan dalam suatu proses persidangan perkara pidana adalah sangat dimungkinkan dan mendasarkan kepada keadaan tersebut maka perkara pidana tersebut wajib dinyatakan gugur.

Pernyataan tentang gugurnya perkara pidana ternyata oleh KUHAP tidak disebutkan secara tegas dan jelas sehingga mengakhiri atau menyelesaikan perkara merupakan jurisdiction valuntaria yang ketentuan Pasal 77 KUHP terhadap

Majelis Hakim mendasarkan kepada kebiasaan dan adanya Surat Edaran Mahkamah Agung Nomor 1 Tahun 1981 yang menerangkan terhadap pernyataan tentang tuntutan Jaksa Penuntut Umum tidak dapat diterima maka wajib dikeluarkan produk hukum berupa putusan sedangkan pernyataan tentang gugurnya penuntutan Jaksa Penuntut Umum hal tersebut tidak diatur sehingga menurut narasumber terhadap kejadian adanya terdakwa meninggal dunia ketika proses persidangan berlangsung hal itu dibuat produk hukum berupa penetapan.

Terhadap gugurnya hak melakukan penuntutan oleh Penuntut Umum sehubungan terdakwa meninggal dunia, secara teoretis, tidak dapat dijatuhkan putusan, oleh karena definisi putusan yang diatur dalam KUHAP hanya meliputi: putusan pemidanaan (Pasal 193 KUHAP), putusan bebas (Pasal 191 KUHAP) dan putusan lepas dari segala tuntutan hukum (Pasal 191 ayat 2 KUHAP). Hal ini bersesuaian dengan pendapat Andi Hamzah, bahwa setiap keputusan hakim merupakan salah satu dari tiga kemungkinan:

a. Pemidanaan atau penjatuhan pidana dan atau tata tertib;

b. Putusan bebas;

c. Putusan lepas dari segala tuntutan hukum; ${ }^{20}$

Sejalan dengan pengertian tersebut di atas maka menurut hukumnya, untuk mendapatkan suatu produk hukum yang benar

dariuslekalawo.blogspot.co.id/2015/05/ap perbedaan-putusan-dan-penetapan.html\#more, diakses 27/04/2016 jam 10.10 Wib. Ibid.
20 Andi Hamzah, 2002, Hukum Acara Pidana Indonesia, Edisi Revisi, J akarta, Sinar Grafika, hlm 280. 
apakah berupa penetapan ataukah berupa putusan dalam hal menyikapi ketentuan Pasal 77 KUHP tersebut maka secara teoretis, sebagaimana dikemukakan oleh Mackenzie yang ditulis oleh Bagir Manan dan ditulis ulang kembali oleh Roby Hermawan Citra, ada beberapa teori atau pendekatan yang dapat dipergunakan oleh hakim dalam mempertimbangkan suatu produk hukum yang akan dijatuhkannya, yaitu : ${ }^{21}$

a. Pendekatan keseimbangan, di mana dalam hal ini, hakim akan mempertimbangkan keseimbangan antara syarat-syarat yang ditentukan oleh undang-undang dengan kepentingan para pihak yang tersangkut dengan perkara, seperti keseimbangan yang berkaitan dengan kepentingan masyarakat, terdakwa, maupun korban atau keseimbangan antara kepentingan pihak penggugat dengan tergugat;

b. Pendekatan seni dan intuisi, di mana dalam penjatuhan putusan, hakim akan menyesuaikan putusannya dengan keadaan agar hukuman yang dijatuhkan wajar bagi setiap pelaku tindak pidana, dan pendekatan ini lebih banyak ditentukan oleh intuisi hakim daripada pengetahuan hakim, sehingga hakim harus lebih berhati-hati dalam menggunakan pendekatan ini;

Roby Hermawan Citra, Problematika Hakim Mengadili Perkara, Majalah Hukum Varia Peradilan, Nomor 352, E disi Maret 2015, hlm 124. c. Pendekatan keilmuan, di mana dalam proses penjatuhan pidana harus dilakukan secara sistematis dan hati-hati, ilmu pengetahuan merupakan rambu peringatan bagi hakim bahwa penjatuhan pidana tidak semata-mata didasarkan pada intuisi hakim semata, akan tetapi harus dilengkapi dengan ilmu pengetahuan hukum dan wawasan keilmuan dari seorang hakim. Hal ini dimaksudkan untuk menjaga konsistensi putusan hakim yang akan dapat memberikan kepastian hukum;

d. Pendekatan pengalaman, merupakan salah satu pengaruh yang dapat memberikan kepada hakim, cara pandang dalam mengadili suatu perkara, yang pada akhirnya bermuara pada sikap hakim dalam penjatuhan putusan. Hakim dengan pengalaman 10 tahun bersidang tentu saja berbeda pengalamannya dengan hakim yang baru 1 tahun bersidang. Akan tetapi, pengalaman ini juga harus tetap didukung oleh moral dan etika serta profesionalitas dari hakim itu sendiri;

Dalam kaitannya dengan penegakan hukum, jika produk hukum yang dihasilkan oleh hakim baik berupa penetapan maupun putusan ditinjau dari penegakan hukumnya, maka melalui penegakan hukum inilah hukum ini menjadikan kenyataan. Menurut Gustav Radburch, sebagaimana ditulis Sudikno 
Mertokusumo, dalam menegakkan hukum ada tiga unsur yang selalu harus diperhatikan, yaitu: ${ }^{22}$

a. Kepastian Hukum (Rechtssicherheid);

b. Kemanfaatan (Zweckmassigkeit); dan

c. Keadilan (Gerechtigkeit);

Penulis dengan adanya perbedaan pandangan tentang gugurnya hak melakukan tuntutan pidana oleh karena terdakwa meninggal dunia yang diatur dalam Pasal 77 KUHP, apakah Majelis Hakim/Hakim mengeluarkan produk hukum berupa penetapan ataukah putusan, maka lebih memiliki dasar hukum yang kuat untuk mengeluarkan produk hukum berupa penetapan. Hal tersebut dikarenakan produk hukum berupa putusan substansinya secara jelas dan tegas telah diatur dalam Pasal 1 angka 11 KUHAP berupa : pemidanaan atau bebas, atau lepas dari segala tuntutan hukum, sedangkan gugurnya hak melakukan penuntutan karena terdakwa meninggal dunia pada dasarnya merupakan pernyataan sepihak dari Majelis Hakim/Hakim menyikapi keadaan tertentu yang terjadi selama proses persidangan, sehingga bentuk penetapan tersebut merupakan bentuk declarotoir semata, namun demikian di dalamnya tetap harus memuat ketentuanketentuan yang terkandung dalam Pasal 197 ayat (1) KUHAP salah satunya kepala "Demi keadilan berdasarkan Ketuhanan Yang Mahaesa". M. Yahya Harahap menyebutkan bahwa, segala penetapan maupun putusan yang dijatuhkan pengadilan tanpa kecuali, harus

22 Sudikno Mertokusumo, et.al, Op.cit, hlm 1 berkepala: "Demi Keadilan Berdasarkan Ketuhanan Yang Maha Esa."23

Keadilan sebagaimana definisi dari Aristoteles adalah memberikan sesuatu kepada setiap orang sesuai dengan apa yang menjadi haknya, maka dalam hal ini dihubungkan dengan dengan asas kemanfaatan yang disampaikan Gustav Radburch, Sudikno Mertokusumo me-nerangkan bahwa, masyarakat meng-harapkan manfaat dalam pelaksanaan atau penegakan hukum. Hukum adalah untuk manusia, maka pelaksanaan hukum atau penegakan hukum harus memberi manfaat atau kegunaan bagi masyarakat. Jangan sampai justru karena hukumnya dilaksanakan atau ditegakkan timbul keresahan di dalam masyarakat. ${ }^{24}$

Pertimbangan hukum tersebut di atas yang melandasi Majelis Hakim mengeluarkan produk hukum berupa penetapan, sehingga terdapat aspek kemanfaatan hukumnya jika diperhatikan dalam pertimbangan hukum dalam suatu penetapan tentang gugurnya hak melakukan penuntutan oleh karena terdakwa telah meninggal dunia.

\section{PENUTUP}

\section{Kesimpulan}

Produk hukum yang deluarkan oleh Pengadilan Negeri sehubungan dengan gugurnya hak melakukan penuntutan oleh karena terdakwa meninggal dunia ketika proses persidangan berlangsung adalah penetapan.

\footnotetext{
23 M.Yahya Harahap, 2003, Pembahasan Permasalahan dan Penerapan KUHAP, Pemeriksaan Sidang Pengadilan, Banding, Kasasi dan Peninjauan Kembali, J akarta,edisi kedua, Sinar Grafika, hlm 359.

24 Sudikno Mertokusumo dan A.Pitlo, 2013, Bab-bab Tentang Penemuan Hukum, Bandung, Citra Aditya Bakti, hlm 2.
} 
Penerapan dalam praktik berupa produk hukum penetapan tersebut harus didasarkan pada pertimbangan hukum yang mencakup aspek kepastian hukum, keadilan dan kemanfaatan.

\section{Saran}

Agar dalam pembaruan hukum pidana ke depan khususnya perubahan Undangundang Nomor 8 Tahun 1981 tentang Kitab Undang-undang Hukum Pidana, terhadap ketentuan tentang gugurnya hak melakukan penuntutan oleh karena terdakwa meninggal dunia sebagaimana ketentuan Pasal 77 KUHP, disebutkan secara jelas dan tegas tentang produk hukum yang harus dikeluarkan oleh hakim.

Majelis Hakim/Hakim lebih baik mengeluarkan produk hukum berupa penetapan terhadap diri terdakwa yang meninggal dunia ketika proses persidangan sedang berlangsung, dan jika ada barang bukti dalam perkara tersebut yang akan dikembalikan kepada keluarga terdakwa maka seharusnya menyebutkan mengembalikan barang bukti perkara pidana tersebut kepada ahli waris terdakwa melalui penuntut umum.

\section{DAFTAR PUSTAKA}

\section{Buku}

Harahap, M. Yahya, 2003, Pembahasan Permasalahan dan Penerapan KUHAP, Pemeriksaan Sidang Pengadilan, Banding, Kasasi dan Peninjauan Kembali, Jakarta,edisi kedua : Sinar Grafika

Hamzah, Andi, 2002, Hukum Acara Pidana Indonesia, Edisi Revisi, Jakarta: Sinar Grafika
Kanter, E.Y dan Sianturi, S.R , 2002, Asas-asas Hukum Pidana di Indonesia dan Penerapannya, Jakarta : Storia Grafika

Kartanegara Sathocid,, tanpa tahun, Hukum Pidana, Kumpulan Kuliah, Bagian Dua, Balai Lektur Mahasiswa

Mertokusumo, Sudikno dan Pitlo, A., 2013, Babbab Tentang Penemuan Hukum, Bandung: Citra Aditya Bakti

Moeljatno, 2007, Kitab Undang-undang Hukum Pidana, Jakarta: Bumi Aksara 2015, Asas-asas Hukum Pidana, Edisi Revisi, Jakarta : Rineka Cipta

Reksodiputro, Mardjono, 1997, Pembaharuan Hukum Pidana, Pusat Pelayanan Keadilan dan Bantuan Hukum, Universitas Indonesia

Salam, Moch. Faisal, 2001, Hukum Acara Pidana dalam Teori dan Praktek, Bandung : Mandar Maju

Zainuddin Ali, 2014, Metode Penelitian Hukum, Jakarta : Sinar Grafika

\section{Peraturan Perundang-undangan}

Indonesia, Undang-undang Nomor 8 tahun 1981 tentang Hukum Acara Pidana

KUHP, 1988, Tim Penerjemah Badan Pembinaan Hukum Nasional, Departemen Kehakiman, Jakarta, Pustaka Sinar Harapan

Indonesia, Undang-undang Nomor 48 tahun 2009 tentang Kekuasaan Kehakiman

Indonesia, Undang-undang Nomor 49 tahun 2009 tentang Peradilan Umum

Buku II Mahkamah Agung RI Edisi 2007 tentang Pedoman Pelaksanaan Tugas dan Administrasi Pengadilan Dalam Empat Lingkungan Peradilan, Jakarta, Mahkamah Agung

\section{J urnal/Majalah}

Majalah Hukum Varia Peradilan, Nomor 352, Edisi Maret 2015

\section{Internet}

https://smjsyariah89.wordpress.com/2011/06/20/ penetapan-dan-putusan/

www.artikelsiana.com/2015/01/pengertiankeadilan-macam-macam-keadilan.html diakses Jumat, 04/03/2016 jam 16.11 Wib. 
P a g e | 519

http://dariuslekalawo.blogspot.co.id/2015/05/apa -perbedaan-putusan-dan-

penetapan.html\#more, diakses 27/04/2016 jam 10.10 Wib.

Zenhadianto.blogspot.co.id/2014/01/teorisistem-hukum-lawrance-mfriedman.html diakses Jum'at 04/02/ 2016 jam 16.20 Wib. 